\title{
Positive Effect of Habits and Learning Method for Improving Student Achievement
}

\author{
Tetty Natalia Sipayung ${ }^{1}$, Sinta Dameria Simanjuntak ${ }^{2}$ \\ ${ }^{12}$ Lecturer, Universitas Katolik Santo Thomas, Jl. Setia Budi No.479F, Tanjung Sari, Kota Medan, Sumatera \\ Utara 20154, Indonesia
}

\begin{abstract}
The purpose of this study is to assess comprehensively the differences in achievement of students who follow the teaching of calculus with the method of discussion and expository method and determine differences in academic achievement of students who have learning habits Delay Avoidance study and habits Work Methods also know the interaction between the learning methods mentioned, this research using a quasi-experimental that conducted in STMIK Pelita Nusantara Medan. Selection of the sample used as the experimental group and the control group were randomized to the study sample with total 55 people consisting of the executive class $A$ with 29 people as a pilot class and executive class B, total 26 people as a control group, the results of data analysis that the students who attend learning calculus with discussion method is better than the students who attend the expository learning method. When viewed from the characteristics of students, academic achievement of students who have learning habits Avoidance Delay higher than students who are having learning habits Work Methods, and when viewed from the interaction, there is an interaction between the learning methods and study habits in influencing academic achievement. Therefore, researchers suggest that learning with discussion method can be used as an alternative for faculty in presenting lessons.
\end{abstract}

Keyword: Method of Discussion, Study Habits, Delay Avoidance Habits, Work Methods Habits

\section{Introduction}

An efforts to improve students 'academic ability through education, lecturers have a crucial role not only see the learning process as the transfer of science and technology but also as a process of developing students' potential. STMIK Pelita Nusantara is one of the private universities in Medan. STMIK Pelita Nusantara is always improving itself to be able to move forward with other universities. Various efforts have been made to the development STMIK Medan Pelita Nusantara in general and special education course. Such as by building a separate lecture building is strategically equipped facilities and infrastructure that support the teaching and learning activities. STMIK Medan Pelita Nusantara opened two types of classes are regular classes and executive class. As for the background of the grouping to help students whose daily routine is already having a job to be able to follow the lectures, observations of researchers learning methods in STMIK Medan Pelita Nusantara has not been effective. In fact, most of the lecturers still apply expository method with the lecture method. In the process of learning activities are still centered on the faculty as a lecturer while students just sit to hear the material. It is considered not efficient and makes the learning activities seem monotonous and boring, especially for students executive class which dominated by students who daily routine is working.

Based on observations and interviews with lecturers calculus courses previously obtained information that a student mastery of the material in the course Calculus less achieve the expected goals. One indicator that could be seen is the average value of final exams in courses Calculus student a few years ago. Hamid (2007) states that factors of learning conditions influence the effect of the method of improving learning outcomes. Also, one part of the learning conditions is variable characteristics of students. So an effort to improve the quality of learning should consider the characteristics of the students. Given the demands of the courses Calculus as continuous basic subjects and much practice, it is one of the efforts that can be done to improve student learning outcomes is to apply the learning method of discussion is a group discussion.Based on the above, it was felt necessary efforts to reveal whether there is actual discussion teaching methods and study habits contribute positively to students' academic ability in the subject of the calculus. That is what pushed need to do a study that focuses on the Positive Effect of Method Discussion and Study Habits to Improve Student Achievement Calculus

\section{Theories}

Learning methods can be interpreted simply as a method or technique delivery of materials by educators to students. The learning method is a method or specifications and techniques that can be used by lecturers to achieve the expected learning. One type of learning method that can be applied is the method of discussion. Discussion method is a way of presenting the lesson, where students exposed to a problem that can be a statement or question that is problematic to be discussed and solved in cooperation with (Djamarah, 2006: 
87). According to Killen (in Sanjaya, 2006) states that the primary purpose of learning the method of discussion is to solve problems, answer questions, increase knowledge and understanding of students, as well as to make a decision. In this study applied a method of small group discussions. In the discussion of learning methods, students divide into several groups. Each team consists of 3-7 people. In the process of implementation of this discussion begins with the lecturer presents a problem in some sub-problems. Each sub-group to solve the problem submitted by the lecturer. The process ends with a discussion of each group report (Sanjaya, 2006: 155).

\section{A. Habits of Study}

The achievement of one's learning strongly influence by the study habits that people do it. Covey (1994: 65) states that the custom is a powerful factor in a person. Habits are behaviors consistent form and often, as well as a pattern that cannot be realized and very typical for each. One thing that is important in forming good study habits is to determine the schedule of learning because with the study schedule can be made of materials known what will be learned and how long the material will be explored and worked. Watkiri (1990: 234) found an effective way of learning that includes making plans to learning, cultivate optimistic split time, immediately start studying, studying books, preventing the buildup of lessons, enhance and speed reading and making notes or a summary of the subject matter.

\section{B. Academic achievement}

Academic achievement has the same meaning as learning outcomes. Learning outcomes are the abilities possessed by students after the students receive their learning experience. Arikunto (1999: 49) defines learning outcomes is the result obtained after the learning activities expressed in the form of numbers, letters and words as well, moderately, quite, less. Definition of learning outcomes by Dick and Reiser (in Nasution, 1999: 56) are the abilities possessed by students as a learning activity. Learning outcomes are essentially the final product of a study expected to changes in a person that expressed in certain behavior. In general, the test used to assess and measure the results of student learning, especially learning outcomes related cognitive mastery of teaching materials following the purpose of education and teaching (Sudjana, 2009: 35).

\section{Evaluation}

The results of field research shows that students who attend the discussion method of learning calculus, calculus was found that the academic achievement of students of 29 respondents had the highest value of 90 ; and the lowest value of 65; the average value of 84.41; median 88.67; 91.70 mode; 9.06 standard deviation and variance of 82.10. Based on the tabulation of data obtained showed four students (13.79\%) whose grades average, 17 students $(58.62 \%)$ who received grades above average, and eight students $(27.59 \%)$ who received grades below average

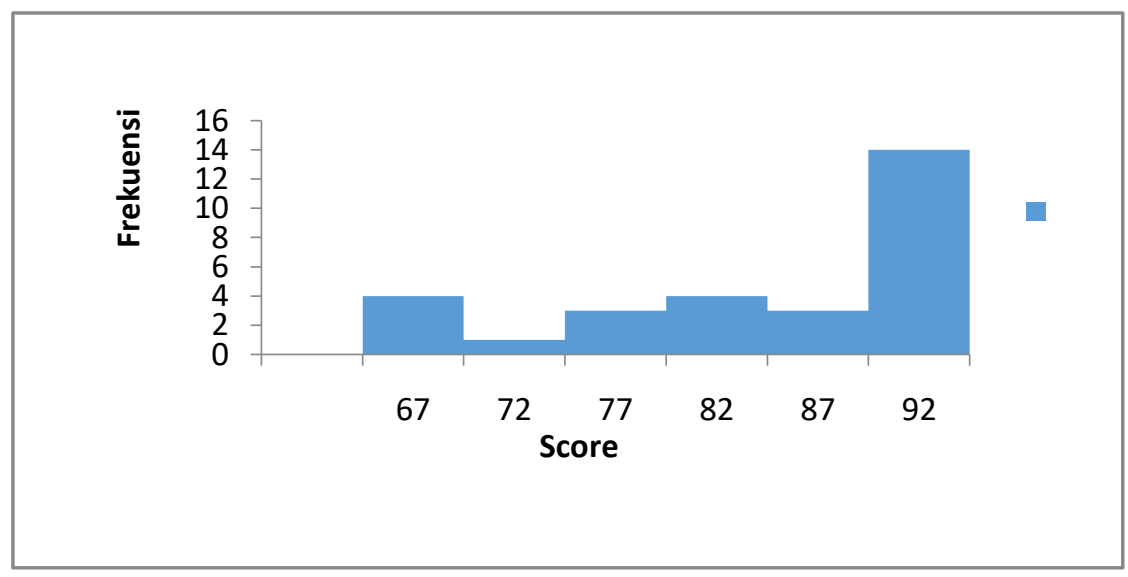

Fig 1. Academic Achievement of Students with Discussion Learning Method

\section{A. Academic Achievement of Students with Expository Learning Method}

The results of field research showed that students in the subject of Calculus for the group following study with expository method, it was found that the students' academic achievement of 26 respondents had the highest value and the lowest value 65 90; value - average 73.73; median 68.83; 67.18 mode; 9.30 standard deviation and variance $86.43 \mathrm{Based}$ on the tabulation of data obtained showed two students (7.69\%) that received an average rating, nine students (34.61\%) were scoring above the average and 15 students (57.69\%) who received grades below average. 


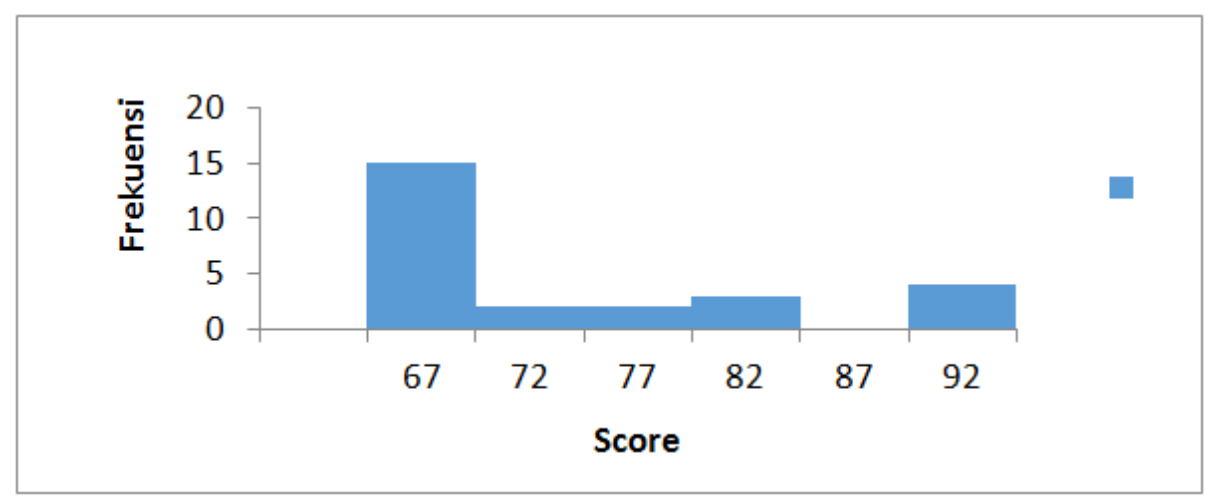

Fig 2. Academic Achievement of Students with Expository Learning Method

\section{B. Academic Achievement of Students with Delay Avoidance Habits Learning}

The results of the study in the field shows that the group of students who Have Habits of Delay Avoidance which follows the method of learning calculus with discussion and expository method, it was found that the students' academic achievement of 34 respondents had the highest value and the lowest value 6590 ; the average value of 82 ; median 86.17; 91.72 mode; 10.78 standard deviation and variance 116.18 . Based on the tabulation of data obtained showed four students $(11.76 \%)$ get an average value, three students $(8.82 \%)$ were scoring above the average, and 16 students $(47.06 \%)$ who received grades below average

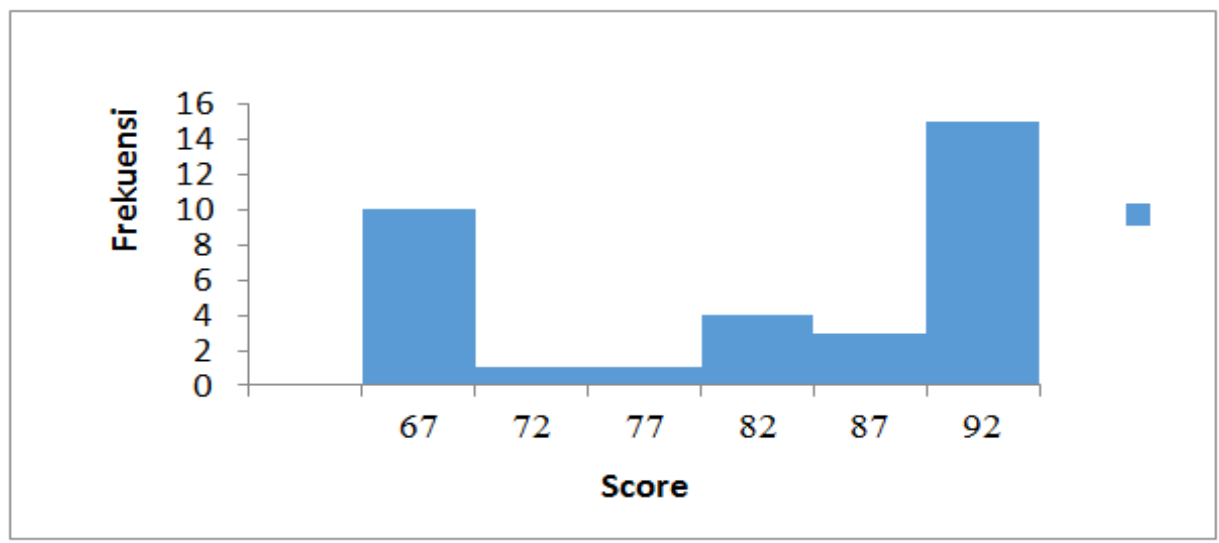

Fig 3. Academic Achievement of Students with Delay Avoidance Habits Learning

\section{Students with Academic Achievement with Work Methods Habits}

The results of research in the field showed a group of students who Have Habits of Work Methods which follows the method of learning calculus with discussion and expository method, it found that the students' academic achievement of 21 respondents had the highest value and the lowest value 6590 ; the average value of 74.07; median 70.23; 68.38 mode; 8.86 standard deviation and variance of 78.53. Based on the tabulation of data obtained showed five students $(23.81 \%)$ whose grades average, 11 students $(52.38 \%)$ who received grades above average, and five students $(23.81 \%)$ who received grades below average

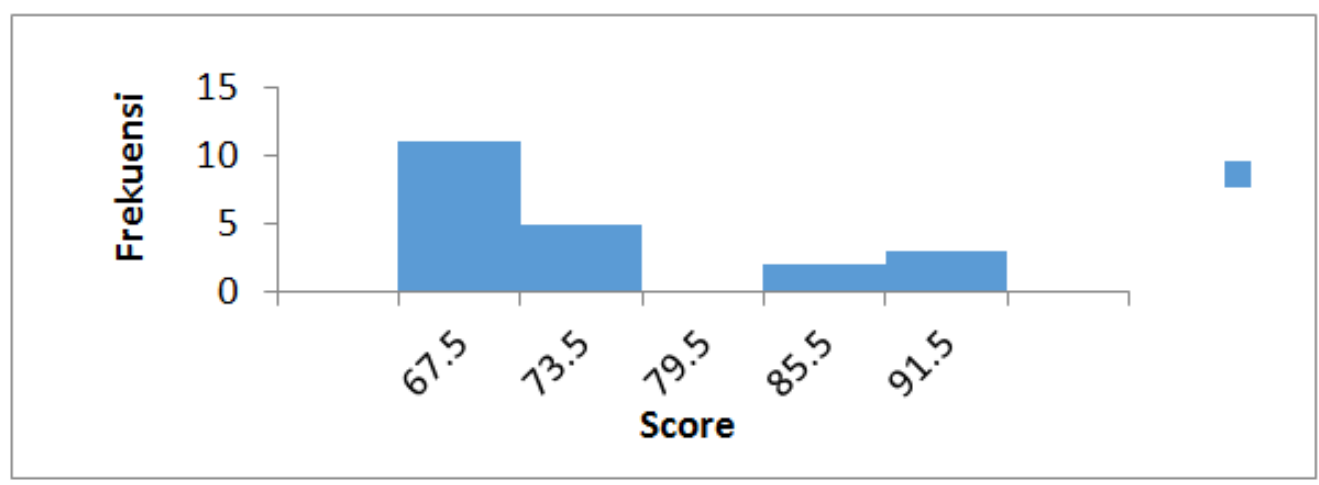

Fig 4. Students with Academic Achievement with Work Methods Habits 


\section{Academic Achievement of Students with Method of Discussion and Delay Avoidance}

The results of the study in the field shows that the group of students who Have Habits of Delay Avoidance and the following study with the method of discussion, it was found that the students' academic achievement of 20 respondents had the highest value and the lowest value 65 90; value - average 83.50; median 89.88; 90.50 mode; standard deviation of 8.29; and the variance of 68.80 . Based on the tabulation of data obtained showed four students $(20 \%)$ get an average value, three students $(15 \%)$ who received grades above average, and 13 students (65\%) who received grades below average

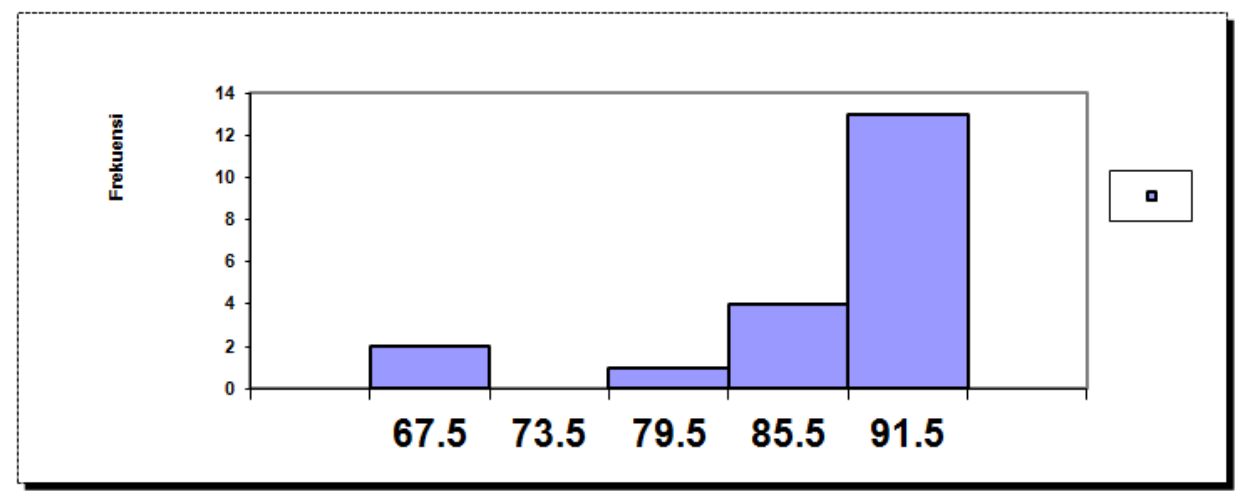

Fig 5. Academic Achievement of Students with Method of Discussion and Delay Avoidance

\section{E. Student Academic Achievement with Discussion and Work Methods}

The results of the study in the field shows a group of students with Habits of work methods and follow the teaching method of debate, it found that the students' academic achievement of nine respondents had the highest value and the lowest value 65 90; value - average 75.78; median 75; 71.50 mode; standard deviation of 6.96; and the variance of 48.39. Based on the tabulation of data obtained showed three students (33.33\%) get an average value, three students $(33.33 \%)$ who received grades above average, and three students $(33.33 \%)$ who received grades below average.

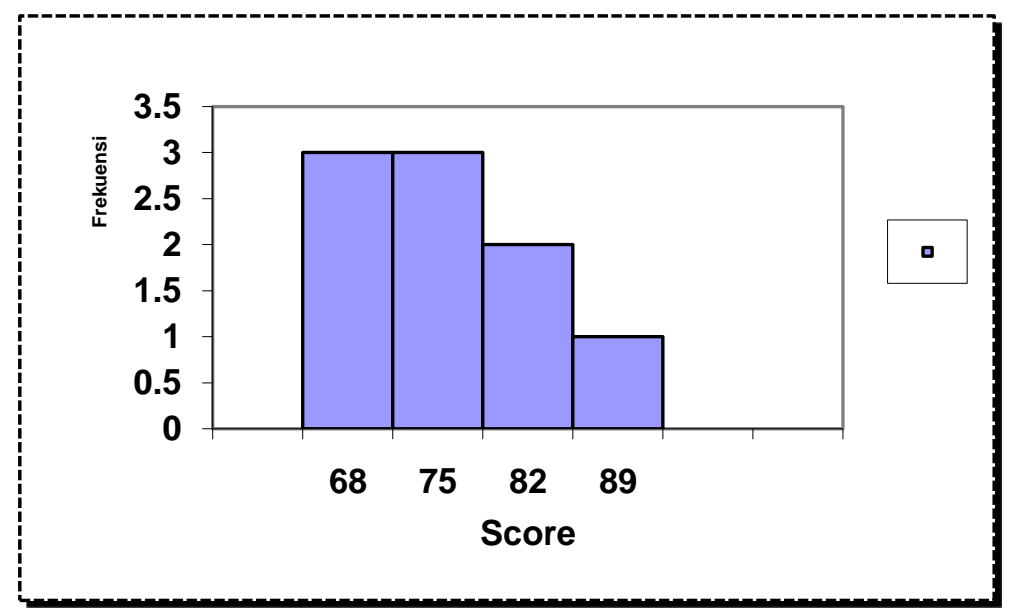

Fig 6. Student Academic Achievement with Discussion and Work Methods

\section{F. Students with Academic Achievement with Expository Delay Avoidance Learning Method}

The results showed that the group of students who have a habit of Delay Avoidance and the following study with expository method, it was found that the students' academic achievement of 14 respondents had the highest value and the lowest value 65 90; value - average 73.50; median 69.75; 82.93 mode; standard deviation of 8.48; and variance 72. Based on the tabulation of data obtained showed two students (14.29\%) get an average value, four students (28.57\%) who received grades above average, and eight students (57.14\%) who received grades below average 


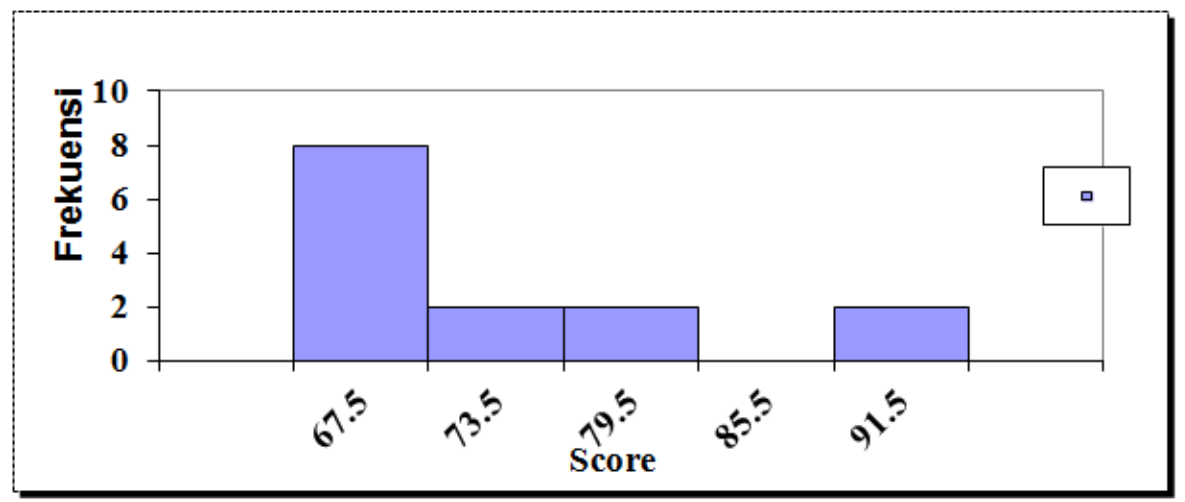

Fig 7. Students with Academic Achievement with Expository Delay Avoidance Learning Method

\section{G. Student Academic Achievement with Expository and Work Methods}

The results of the study in the field shows that the group of students who have a habit of Work methods and following study with expository method, it was found that the students' academic achievement of the 12 respondents who have the highest value and the lowest value 65 90; value - average 73.50; median 69; 67.70 mode; standard deviation of 9.49; and variance 90 . Based on the tabulation of data obtained showed one student $(8.33 \%)$ that received an average rating, three students $(25 \%)$ who received grades above average, and eight students $(66.67 \%)$ who received grades below average.

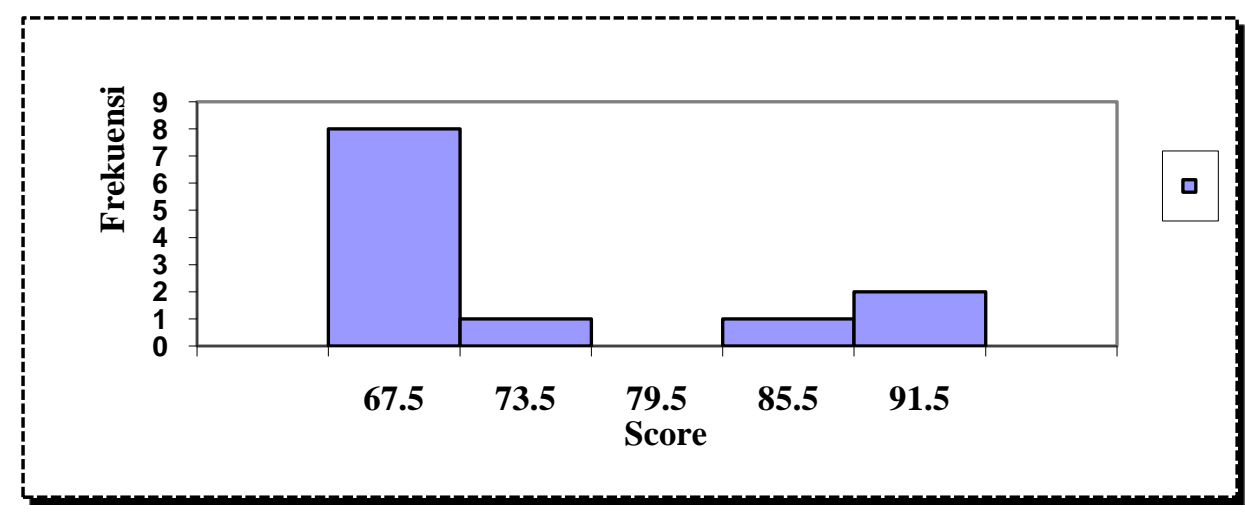

Fig 8. Student Academic Achievement with Expository and Work Methods

Based on the data processing can be inferred about the research hypothesis testing is as follows:

1. $\mathrm{F}^{\text {count }}=12$ 906> $\mathrm{F}$ table $=3.44$ (for $\mathrm{a}=5 \%$ ), which shows that there are differences in academic achievement of students taking calculus teaching method of discussion with the expository method.

2. $\quad \mathrm{F}^{\text {count }}=4.144>\mathrm{F}$ table $=3.44$ (for $\mathrm{a}=5 \%$ ), which indicates there is a difference in students who are having academic learning habits Delay Avoidance with study habits Work Methods.

3. $\mathrm{F}^{\text {interaction }}=4,360>\mathrm{F}$ table $=3.44$ (for $\mathrm{a}=5 \%$ ), which indicates there is interaction between the learning methods and study habits in affecting students' academic achievement

TABLE I: Homogeneity Test

Levene's Test of Equality of Error Variances

Dependent Variable: Learning Result

\begin{tabular}{|c|c|c|c|}
\hline $\mathrm{F}$ & $\mathrm{df} 1$ & $\mathrm{df} 2$ & Sig. \\
\hline 1,248 & 3 & 51 &, 302 \\
\hline & & & \\
\hline
\end{tabular}

Test of the null hypothesis that the error variance of the dependent variable is equal across groups.

Design: Intercept + Learning_Method +

Study_Habits + Learning_Method $*$ Study_Habits

The table above shows the value table (Significance) Sig. 0,302 were $>0.05$ so that the same can be said variant or homogeneous. Figures Levene Statistic shows the smaller the value, the greater homogeneity. 
TABLE II: Normality Test One-Sample Kolmogorov-Smirnov Test

\begin{tabular}{|c|c|c|c|c|}
\hline & & Learning Method & Habits & $\begin{array}{c}\text { Academic } \\
\text { achievement }\end{array}$ \\
\hline $\begin{array}{l}\text { Normal Parameters } \\
\text { a,b } \\
\text { Most Extreme Differences } \\
\text { Kolmogorov-Smirnov Z } \\
\text { Asymp. Sig. (2-tailed) }\end{array}$ & $\begin{array}{l}\text { Mean } \\
\text { Std. Deviation } \\
\text { Absolute } \\
\text { Positive } \\
\text { Negative }\end{array}$ & $\begin{array}{c}55 \\
1,47 \\
, 504 \\
, 353 \\
, 353 \\
-, 325 \\
2,619 \\
, 060\end{array}$ & $\begin{array}{c}55 \\
1,38 \\
, 490 \\
, 400 \\
, 400 \\
-, 278 \\
2,967 \\
, 070\end{array}$ & $\begin{array}{c}55 \\
77,60 \\
10,806 \\
, 224 \\
, 224 \\
-, 202 \\
1,659 \\
, 080\end{array}$ \\
\hline
\end{tabular}

Table Kolmogorov-Smirnov normality test showed that the value Asymp. Sig. (2-tailed) of 0.06, 007 and 0.08 it is greater than 0.05 so data teaching methods, study habits and academic achievement of students in the normal distribution.

\section{Conclusion}

Based on the results of hypothesis testing following the discussion can be concluded that:

1. There is a difference in the academic achievement of students who follow the method of learning calculus talks with the expository method. Academic Achievement students who attend the learning method using discussion method was significantly better than the students who participate in the expository learning method. The result shows the positive influence the discussion method in improving students' academic achievement.

2. There is a difference in the academic achievement of students who have learning habits Delay Avoidance with study habits Work Methods. Academic achievement of students who have learning habits Delay Avoidance was significantly better than the habit of Work Methods. The result shows the positive influence study habits in improving student academic achievement.

3. There is an interaction between the learning methods and study habits in improving student academic achievement. The evident from the research that students who have a habit Delay Avoidance received academic performance is better for students who follow the teaching method of discussion while students who have learning habits Work Methods gained academic performance is better for students to follow learning calculus with the expository method.

\section{References}

[1] Arikunto, S., (1999), Dasar-Dasar Evaluasi Pendidikan (Edisi Revisi), Jakarta : Bumi Aksara.

[2] Covey, S.R., (1994) Tujuh Kebiasaan Manusia yang Efektif, (penterjemah: Budijanto), Jakarta : Binarupa Aksara.

[3] Djamarah, S. B., dkk., (2006), Strategi Belajar Mengajar, Jakarta : PT. Rineka Cipta.

[4] Hamid, A., (2007), Teori Belajar dan Pembelajaran, Medan: Program Pascasarjana Unimed.

[5] Nasution, S., (1999), Kurikulum dan Pengajaran, Jakarta : Bumi Aksara.

[6] Sanjaya, W., (2006), Strategi Pembelajaran Berorientas Standar Proses Pendidikan, Jakarta : Kencana.

[7] Sudjana, Nana, (2009), Penilaian Hasil Proses Belajar Mengajar, Bandung : PT. Remaja Rosdakarya.

[8] Watkiri, H., dkk., (1990), Penilaian Pencapaian Hasil Belajar, Jakarta : Universitas Terbuka. 